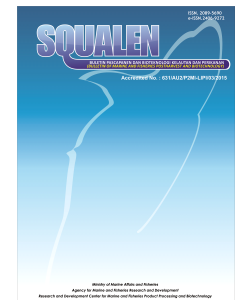

\title{
Effect of Alginate and Polyethylene Glycol Addition on Physical and Mechanical Characteristics of к-Carrageenan-based Edible Film
}

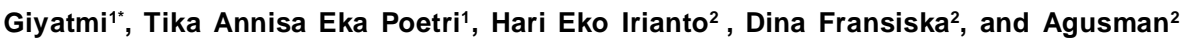 \\ ${ }^{1}$ Study Program of Food Technology, Sahid University, Jakarta \\ JI. Prof. DR. Soepomo, Tebet, South Jakarta, Indonesia \\ ${ }^{2}$ Research and Development Center for Marine and Fisheries Product Processing and Biotechnology \\ Jl. Ks Tubun Petamburan VI, Slipi, Central Jakarta, Indonesia \\ Article history: \\ Received: 19 December 2019; Revised: 4 April 2020; Accepted: 21 May 2020
}

\begin{abstract}
Waste disposal problems have attracted scientists around the world to explore the use of renewable resources to produce biodegradable films and coatings. Indonesia has diverse renewable resources of biopolymers that originated from seaweeds such as carrageenan, agar, and alginate. Carrageenan is considered as a potential biopolymer for edible film manufacture due to its characteristic range. This study aimed to develop carrageenan-based edible film using alginate and polyethylene glycol as plasticizers. Edible film made from $\kappa$-carrageenan with the addition of alginate and polyethylene glycol (PEG) as plasticizers was tested for its mechanical properties, water vapor transmission rate (WVTR) and water solubility. Blending $\kappa$-carrageenan with alginate $(0 \%, 0.25 \%, 0.5 \%, 0.75 \%$, and $1.0 \% \mathrm{w} / \mathrm{v}$ ) increased tensile strength, thickness, and water solubility, but reduced elongation at break, WVTR, and moisture content. The addition of PEG $(1 \%, 2 \%$, and $3 \% \mathrm{w} / \mathrm{v})$ reduced tensile strength and water solubility, but increased elongation at break, thickness, and moisture content. This study recommended that the best carrageenanbased edible film was obtained from a formula using $1 \%$ alginate $(\mathrm{w} / \mathrm{v})$ and $1 \%$ PEG $(\mathrm{w} / \mathrm{v})$.
\end{abstract}

Keywords: alginate, edible film, $\kappa$-carrageenan, polyethylene glycol

\section{Introduction}

Renewable, degradable, and edible films have attracted scientists around the world, including Indonesia to develop food and non-food packaging applications. Edible film characteristics such as good biodegradability, biocompatibility, environmental friendliness, availability and even edibility (Salmieri \& Lacroix, 2006) support its application as food packaging. Biodegradable films represent eco-friendly food packaging because they are constructed using natural polymeric ingredients such as sodium alginate and carrageenan (Ma, Jiang, Ahmed, Qin, \& Liu, 2019). The films can inhibit the reduction of food quality by limiting the loss of moisture and reducing the rate of unwanted chemical reactions. Edible films can prevent food spoilage and microbial contamination in food products (Sánchez-Ortega et al., 2014). Edible films also offers excellent barriers to oxygen and carbon dioxide. Good mechanical properties of edible films are usually determined by its water-solubility of hydrocolloids such as carrageenan and alginate. Carrageenan and alginate have been explored as sources of film-forming material (Tavassoli-Kafrani, Shekarchizadeh, \& Masoudpour-Behabadi, 2016).

Edible film is eatable film usually used for food coating and is generally made from natural ingredients such as polysaccharides, proteins, fats or a combination of those materials (Cerqueira et al., 2011). Indonesia has diverse biopolymers originated from seaweed, such as carrageenan, agar and alginate, which considered as promising natural renewable materials for biofilm and bioplastic production because of its cost-effective, biodegradability and non-toxic properties (Meng et al., 2018; Rajendran, Puppala, Raj, Sneha, \& Rajam, 2012).

Red seaweed (Eucheuma cottonii) is a source of $\kappa$-carrageenan which is very abundant in Indonesian water (KKP, 2014). Hence, it is a potential renewable sources for natural biofilm industry in Indonesia. As a source of linear sulphated polysaccharides $\kappa^{-}$

*Corresponding author.

E-mail: giyatmi@hotmail.com

Copyright (C) 2020, Squalen BMFPB. Accreditation Number: 21/E/KPT/2018.

DOI: http://dx.doi.org/10.15578/squalen.v15i1.418 
carrageenan- is soluble in hot water, and forms a strong gel at room temperature (Fardhyanti \& Julianur, 2016; Imeson, 2000; Menon, 2011). Even though $\kappa-$ carrageenan has the ability to form a strong gel, this carrageenan is capable of forming an edible film with low tensile strength and low elasticity (Pascalau et al., 2012). Therefore, other compounds are required to improve the mechanical properties of carrageenanbased edible film. Alginate is an alternative material recommended to improve the performance of the film.

Alginate, a linear copolymer containing block of $(1,4)$ - linked $\beta$-D-mannuronate $(M)$ and $\alpha$-L-guluronate $(G)$ residues, is a naturally occurring anionic polymer typically obtained from brown seaweed such as Sargassum, Laminaria, Ascophyllum (Lee \& Mooney, 2012). Alginate produced a film with higher tensile strength and elongation than that of carrageenan (Pascalau et al., 2012). The combination of $\kappa$ carrageenan and alginate is expected to produce an edible film expressing mixed characteristics of both hydrocolloids to increase its tensile strength and elongation. The mechanical and physical properties of edible film can be further improved by introducing a plasticizer in the formula.

The plasticizer is needed to produce a thin edible film with smooth surfaces (Murdinah, Darmawan, \& Fransiska, 2007). The preferred characteristics of plasticizers are small size, high polarity, more polar groups per molecule, and more distance between polar groups in the molecule, that increase the effect of plasticization on the polymer system (Rodriguez, Madera, \& Pelegrín, 2018). Making polysaccharides or protein-based edible films generally requires plasticizers (Skurtys et al., 2010). Several compounds have been used as plasticizers for edible film production e.g., glycerol, sorbitol and polyethylene glycol (PEG) (Balqis, Khaizura, Russly, \& Hanani, 2017). PEG affected the physical and mechanical properties of edible film, which produced thicker, higher tensile strength, and higher WVTR film (Marpongahtun, 2016). In addition, it is a safe, odorless, oily and nonvolatile polymer, mainly used as a solvent, dispersing agent, and suppository base in medical application (Abdel-Rahman, Abdel-Mohsen, Fouda, Al Deyab, \& Mohamed, 2013). This study aimed to investigate the effect of alginate and PEG as plasticizers on the mechanical and barrier properties of $\kappa$-carrageenanbased edible films. Alginate was used to improve tensile strength and PEG was employed to improve elongation. This study investigated the mixture of alginate and PEG with $\kappa$-carrageenan as a new composite to take advantages from possible synergistic effects in forming gel based on their mechanical and WVTR properties.

\section{Material and Method}

\subsection{Material}

Sodium alginate and $\kappa$-carrageenan were extracted from Sargassum sp. and E. cottonii, respectively. Characteristics of $\kappa$-carrageenan and alginate are shown in Table 1. The polyethylene glycol /PEG 400 (Sigma-Aldrich, Singapore) was used as plasticizers.

\subsubsection{Preparation of $\kappa$-carrageenan}

E. cottonii, as the source of $\kappa$-carrageenan, was harvested from the Serang waters, Banten - Indonesia. $\kappa$-carrageenan was extracted using a method previously described by Peranginangin, Rahman, \& Irianto (2011). Dried E. cottonii was soaked in water for $30 \mathrm{~min}$, washed and rinsed several times. The seaweed was treated using $8 \%$ Potassium Hydroxide $(\mathrm{KOH})$ at $60-65^{\circ} \mathrm{C}$ for $120 \mathrm{~min}$. The seaweed was then rinsed with water and extracted using water at $80-85^{\circ} \mathrm{C}$ for $120 \mathrm{~min}$ with stirring regularly. Celite (3\% by weight) was added during extraction process (Peranginangin et al., 2011). The extract was filtered using a filter press, then cooled to $25^{\circ} \mathrm{C}$. As much $1 \%$ Potassium Chloride $(\mathrm{KCl})$ solution with a ratio of filtrate: $\mathrm{KCl}$ solution of $1: 2(\mathrm{v} / \mathrm{v})$ was added into the filtrate, and continuously stirred for 30 min until the formation of $\kappa$-carrageenan gel. The gel was put in the filter cloth, pressed and sun dried.

Table 1. Characteristics of $\kappa$-carrageenan and alginate used as film forming materials

\begin{tabular}{lcc}
\hline \multicolumn{1}{c}{ Characteristics } & k-carrageenan & Alginate \\
\hline Yield $(\%)$ & $23.89 \pm 2.40$ & $31.24 \pm 3.32$ \\
Moisture content $(\%)$ & $11.24 \pm 0.35$ & $8.23 \pm 0.13$ \\
Ash content $(\%)$ & $31.15 \pm 0.92$ & $13.95 \pm 0.75$ \\
Viscosity $(\mathrm{cP})$ & $\mathrm{NA}$ & $37.00 \pm 0.87$ \\
Gel strength $\left(\mathrm{g} / \mathrm{cm}^{2}\right)$ & $270.62 \pm 0.63$ & $\mathrm{NA}$ \\
\hline
\end{tabular}

Note: NA : not analyzed 


\subsubsection{Preparation of sodium alginate}

Sargassum sp. was purchased from Binuangeun, Banten, Indonesia. Extraction of alginate from Sargassum sp. was conducted using a method developed by Yunizal (2000). Dried Sargassum sp. was submerged in $1 \%$ Hydrogen Chloride $(\mathrm{HCl})$ for 60 min, washed and rinsed several times. The seaweed was extracted using $2 \%$ Sodium Carbonate $\left(\mathrm{Na}_{2} \mathrm{CO}_{3}\right)$ $(\mathrm{w} / \mathrm{v})$ at $60-70^{\circ} \mathrm{C}$ for $120 \mathrm{~min}$ and stirred regularly. $\mathrm{A}$ vibrator screen was employed to filter the extract. After the filtrate was cooled to $25^{\circ} \mathrm{C}, 10 \% \mathrm{HCl} \mathrm{v/v}$ was added and rinsed several times. Thirty percent of Sodium Hydroxide $(\mathrm{NaOH})(\mathrm{v} / \mathrm{v})$ was then added to obtain $\mathrm{pH} 8$ and subsequently poured into isopropyl alcohol (IPA) with a proportion of filtrate to IPA of approximately $1: 2(\mathrm{v} / \mathrm{v})$ and continuously stirred for 30 min until the formation of alginate gel. The gel was transferred into the filter cloth, pressed and sun dried.

\subsection{Method}

\subsubsection{Preparation of edible film}

Edible film was prepared using solvent casting method by casting film forming solution on the $16 \mathrm{~cm}$ $x 16 \mathrm{~cm}$ acrylic plates and subsequently dried (Fransiska, Giyatmi, Irianto, Darmawan, \& Melanie, 2018). The film forming solution was prepared by dissolving $\mathrm{\kappa}$-carrageenan $(1 \% \mathrm{w} / \mathrm{v})$ and alginate $(0 \%$, $0.25 \%, 0.5 \%, 0.75 \%$, and $1.0 \%$ of $\mathrm{w} / \mathrm{v}$ ) simultaneously in distilled water and mixed thoroughly using a magnetic stirrer at $80^{\circ} \mathrm{C}$ for $15 \mathrm{~min}$. PEG was then added $(1 \%, 3 \%, 5 \% \mathrm{w} / \mathrm{v})$. The mixture was heated at $80^{\circ} \mathrm{C}$ for another 10 min until a homogeneous solution was obtained. The mixture was casted on acrylic plate and dried at $40^{\circ} \mathrm{C}$ for $24 \mathrm{~h}$ to form a film. The dried films were manually peeled off from the acrylic plate and then stored in a desiccator at $25 \pm 2^{\circ} \mathrm{C}$ for $48 \mathrm{~h}$.

\subsubsection{Edible film characterizations}

\subsubsection{Tensile strength and elongation}

Tensile strength and elongation of edible film were measured using Texture Analyzer (TAXT Plus, Stable Micro System, UK) (Balqis et al., 2017) with modification on the sample and measurement method. Films were cut into $2 \mathrm{~cm} \times 15 \mathrm{~cm}$ and fixed in a film grip. The measurements were made with $10 \mathrm{~cm}$ initial distance of grip separation, $3 \mathrm{~mm} / \mathrm{s}$ test speed and 3 $\mathrm{g}$ trigger force. Tensile strength (maximum force/initial cross-sectional area) and elongation values at break were determined using a software package of Texture Expert V.1.15 with the following equations:

$$
\begin{aligned}
& \text { Tensile strength: }(F \times a) / A \\
& \text { Elongation: }\left(L_{1}-L_{0}\right) / L_{0} \times 100 \%
\end{aligned}
$$

Note:

F: Force $(\mathrm{N})$; a: $9.8 \mathrm{~m} / \mathrm{s}^{2}, A$ : thickness $\mathrm{x}$ film wide $\left(m^{2}\right), L_{0}$ : Initial film length $(m), L_{1}$ : Length of film when it is broken $(\mathrm{m})$

\subsubsection{Water vapor transmission rate (WVTR)}

WVTR of edible film was measured according to a method described by Razzaq et al. (2016). WVTR was gravimetrically determined using metal cups equipped with an exposed area metal disc. Edible film was sealed in a metal cup containing distilled water, and then cup was placed in an incubator at $37^{\circ} \mathrm{C}, \pm 24 \% \mathrm{RH}$ for $24 \mathrm{~h}$. The mass of water loss was measured. The WVTR is the rate of water mass loss at the specific area for $24 \mathrm{~h}\left(\mathrm{~g} / \mathrm{m}^{2} / 24 \mathrm{~h}\right)$.

\subsubsection{Thickness}

A digital micrometer (Mitutoyo, Japan) with an accuracy level of $0,001 \mathrm{~mm}$ was used to measure the thickness of edible films. Thickness was randomly measured from ten spots of each film, and the average value was calculated and reported as thickness in millimeters ( $\mathrm{mm}$ ).

\subsubsection{Water solubility}

Water solubility was measured by weighing a $3 x$ $3 \mathrm{~cm}^{2}$ cut film and placed in an aluminum cup containing $50 \mathrm{~mL}$ distilled water, and then heated to $100^{\circ} \mathrm{C}$ for $30 \mathrm{~min}$ (Murni, Pawignyo, Widyawati, \& Sari, 2013). After the cup was sealed to prevent water evaporation, it was subsequently incubated at $25^{\circ} \mathrm{C}$ and periodically shaken for $24 \mathrm{~h}$. Undissolved film was dried in an oven at $40^{\circ} \mathrm{C}$ until a constant weight of the film was achieved.

$$
\text { Water solubility }(\%)=(\text { Wo-Wf }) / \text { Wo } \times 100 \%
$$

Note:

$W_{0}$ : initial dry weight of the film, $W_{f}$ : weight of the insoluble film

\subsubsection{Moisture content}

The moisture content of edible films was measured according to a method described by Farhan \& Hani (2017). Edible film was cut into $2 \times 2 \mathrm{~cm}^{2}$ strips and placed on crucible porcelain dishes for moisture content analysis. 


\subsubsection{Statistical analysis}

Experiments were conducted in triplicates. The data were analyzed using ANOVA followed by Tukey's post-hoc test. The significance level was defined as $\mathrm{P}<0.05$ (Page, Braver, \& Mackinnon, 2003). Since there is no standard for edible film available in Indonesia, SNI (Indonesian National Standard) 7818:2014 for biodegradable plastic bags was used to compare the parameter values measured in this study.

\section{Results and Discussion}

\subsection{Tensile Strength}

Tensile strength values of $\kappa$-carrageenan based edible film are presented in Figure 1. The film tensile strength significantly increased along with the increasing of alginate proportion in the film. Meanwhile, the tensile strength of film significantly decreased along with the increasing PEG proportion in the film. Tensile strength of carrageenan-based film in this study varied between $2.83 \pm 0.16$ to $43.13 \pm 0.33 \mathrm{MPa}$. SNI 7818:2014 describes that minimum tensile strength for biodegradable plastic bag is $13.7 \mathrm{MPa}$. Thus, the tensile strength of edible films with PEG $1 \%$ addition (15.18-43.13 MPa) met the standard for a biodegradable plastic bag. An important requirement of edible films for food packaging is good mechanical properties. Poor elasticity or strength of film potentially leads to premature cracking during production, handling, storage and consumption (Sothornvit \& Rodsamran, 2008). Tensile strength and elongation at break are properties mostly investigated by edible film developers. Tensile strength represents the resistance of the film to elongation or its stretching capacity (Ma, Jiang, Ahmed, Qin, \& Liu, 2019).

The highest and lowest tensile strength for $\kappa$ carrageenan-based edible film were obtained from mixture with $1 \%$ alginate and $1 \%$ PEG; and $0 \%$ alginate and $5 \%$ PEG, respectively. The tensile strength of the $\kappa$-carrageenan-based edible film at a certain level of $P E G$ significantly increased $(P<0.05)$ along with the addition of alginate. By increasing the alginate level in the mixture, the films became stronger with higher tensile strength values, probably due to the presence of a linear structure of alginate. This result was similar to a study by Ye et al. (2017) which reported that through proper blending between carrageenan and alginate, a slower cross-linking has occurred, and it enhanced material uniformity and mechanical strength.

Results from the current study revealed that the addition of PEG as a plasticizer reduced tensile strength. This observation was in accordance with a study by Rachmawati, Triwibowo, \& Widianto (2015) which mentioned that plasticizer addition decreased the tensile strength of chitosan-based edible film. Bourtoom (2008) described that the involvement of a plasticizer agent in biodegradable film manufacture

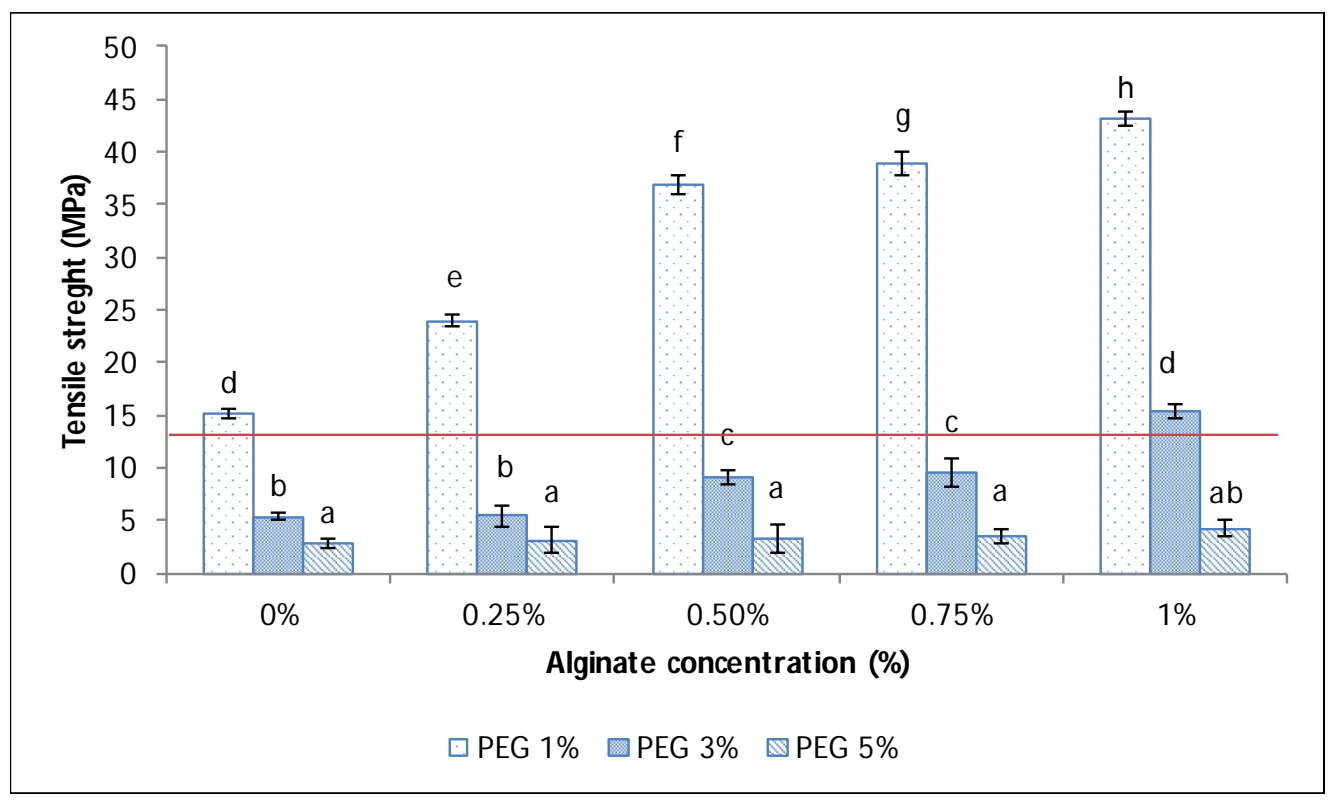

*Note: The same letter in the bar denotes no significant differences $(P>0.05)$

Figure 1. Tensile strength of $\kappa$-carrageenan-based edible films at different concentrations of alginate and PEG mixture compared to the minimum standard of the tensile strength (SNI 7818:2014 in red line) 
reduced brittleness of polymer packaging by disrupting the hydrogen bonds between polymer chains. The size of the plasticizer molecule is relatively small, and it is easier to distribute between the polymer bonds and to break the polymer chain efficiently.

\subsection{Elongation}

Elongation of $\kappa$-carrageenan-based edible films at different levels of alginate and $P E G$ varied between $2.33 \pm 0.15 \%$ to $13.33 \pm 1.11 \%$ (Figure 2 ), while the elongation value for biodegradable plastic bags as mentioned in SNI 7818:2014 is between $400-$ $1,120 \%$. In fact, all carrageenan-based films developed in this study showed a small elongation percentage compared to the standard of biodegradable plastic bags, which probably due to the utilization of alginate and carrageenan as natural polymer in the film. Natural polimer usually produced a smaller elongation percentage than a syntetic polymer (Prachayawarakorn \& Pomdage, 2014)

Elongation is a percentage increase in the length of the edible film measured from the initial length of withdrawal to breaking up of the films (Krochta \& De Mulder-Johnston, 1997). The highest elongation of $\kappa-$ carrageenan-based edible film was obtained from the mixture with $0 \%$ alginate and 5\% PEG. Generally, the addition of different levels of alginate and PEG in the film was significantly affected the elongation value of carrageenan-based edible films.

In this study, the elongation of edible films significantly increased with the addition of PEG but decreased with the addition of alginate $(P<0.05)$. Several authors reported the trend of increasing elongation and decreasing the tensile strength of edible film by the addition of plasticizer (Ahmadi, Kalbsi-Ashtari, Oromiehie, Yarmand, \& Jahandideh, 2012; Larotonda, Torres, Gonçalves, Sereno, \& Hilliou, 2016; Olivas \& Barbosa-Canovas, 2008; Wypych, 2004). PEG as a plasticizer significantly affected the elongation of edible film, as a results of the reduced intermolecular forces between polymer chains after the addition of PEG (Šešlija et al., 2018).

Han \& Gennadios (2005) classified the elongation of film into four categories, i.e., inferior ( $<1 \%)$, marginal (1-10\%), good (>10-100\%) and superior (>100\%). In our study, $\kappa$-carrageenan-based films with $3 \%$ or $5 \%$ PEG and $0 \%$ alginate produced a "good" elongation, while others composition of PEG and alginate mixture resulted in "marginal" elongation.

\subsection{Water Vapor Transmission Rate}

Water vapor transmission rate (WVTR) is the most important and extensively studied properties for edible films because of its association with deteriorative reactions in foods (Ahmadi et al., 2012). A low WVTR value prevents moisture transfer between food and surrounding atmosphere (Bajpai et al., 2011). In our study, the WVTR values of $\kappa$-carrageenan-based edible films at different levels of alginate and PEG varied between $3.12 \pm 0.50$ to $7.68 \pm 0.19 \mathrm{~g} / \mathrm{m}^{2} / 24 \mathrm{~h}$ (Figure 3). $\kappa$-carrageenan-based edible film with the highest WVTR was obtained through the addition of $0 \%$ alginate and $1 \%$ PEG. An edible film with the lowest

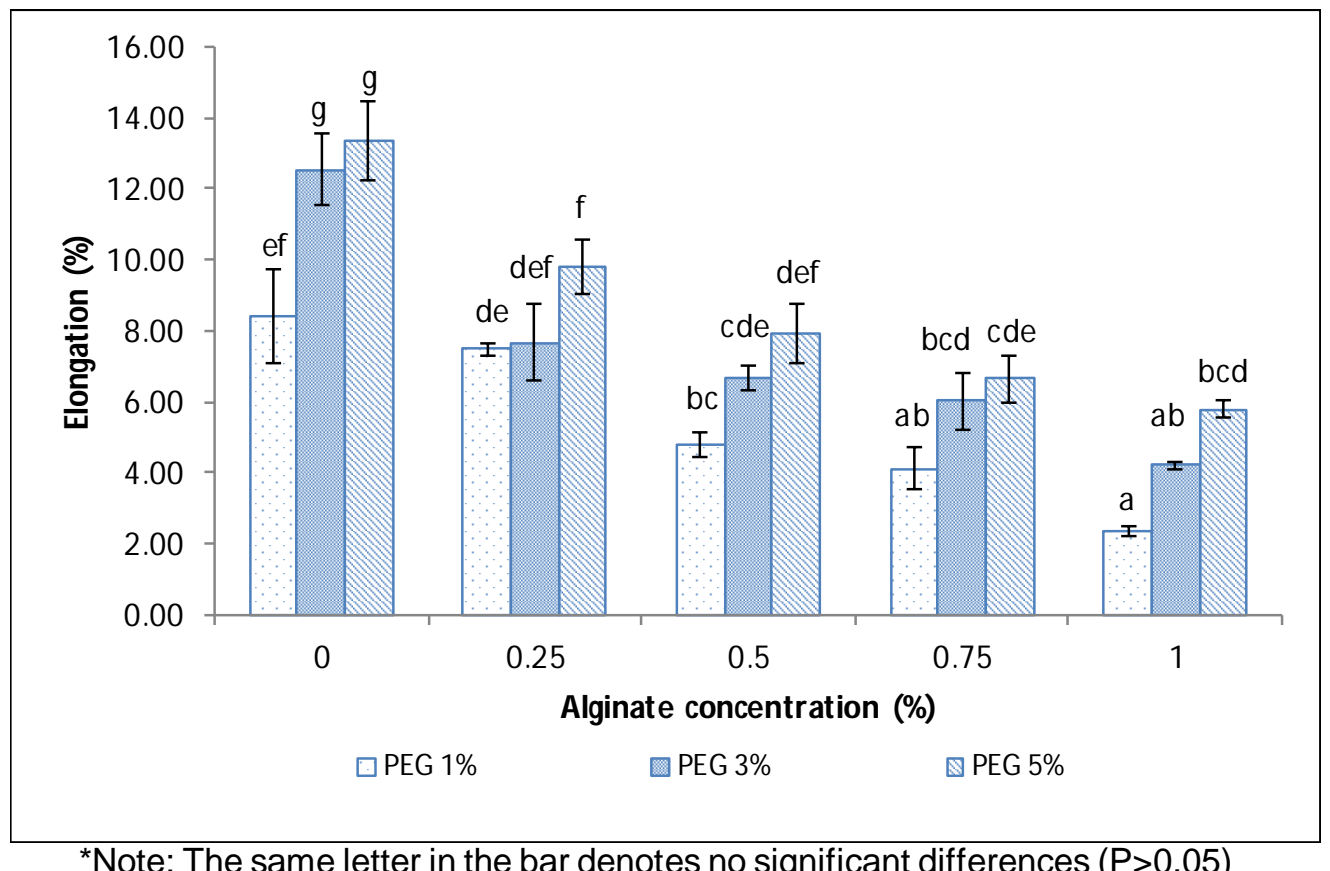

Figure 2. Elongation of $\kappa$-carrageenan-based edible films at different concentrations of alginate and PEG 
WVTR was observed from edible film with $1 \%$ alginate and $5 \%$ PEG. WVTR of $\kappa$-carrageenan-based edible film decreased with the addition of alginate. The addition of PEG in the $\kappa$-carrageenan-based edible film did not significantly affected WVTR value $(P>0.05)$. The water barrier of $\kappa$-carrageenan-based edible film increased with increasing concentration of alginate. These results were in accordance with a study by Murdinah et al. (2007) where the addition of alginate produced the film with lower WVTR. This occurrence was probably due to the nature of alginate, which was able to bind water better (Tavassoli-Kafrani et al., 2016). As a consequence, the film mixture produced a gel matrix which can decrease the WVTR of edible film.

\subsection{Thickness}

The thickness of $\kappa$-carrageenan-based edible film at different levels of alginate and PEG varied from $0.037 \pm 0.006 \mathrm{~mm}$ to $0.084 \pm 0.002 \mathrm{~mm}$ (Figure 4). The thickness of edible films significantly increased with increasing level of alginate and PEG $(P<0.05)$. The film thickness is an essential parameter for packaging (Suryaningrum, Basmal, \& Nurochmawati, 2005). The film thickness depended on the film composition and processing parameters (Garcia, Pinotti, Martino, \& Zaritzky , 2009), and the amount of dissolved soluble in the film-forming solution (Murni et al., 2013). The increasing of thickness also occurs due to the rise in the total amount of solids in the film-forming solution. Increasing the total amount of solids in the solution brings more polymers as matrix constituents. Thickness was influenced by the viscosity and constituent polymers as well (Lismawati, 2017).

As shown in Figure 4, the addition of alginate and PEG increased the thickness of the edible film as the consequence of the increasing the amount of dissolved solids in the edible film (Sitompul \& Zubaidah, 2017). The PEG as a plasticizer absorbed and bond more moisture to some extent and led to an increase in the film thickness (Sitompul \& Zubaidah, 2017). An edible film should be thin enough, so it will be acceptable when it is applied for food product (Han \& Gennadios, 2005). Generally, the edible film thickness is less than $0.3 \mathrm{~mm}$ (Pavlath \& Orts, 2009). Edible film from sugar palm fruit with polyethylene glycol was thicker $(0.226$ $\mathrm{mm}$ ) (Sitompul \& Zubaidah, 2017) than $\kappa$-carrageenanbased film with addition alginate and PEG. The thickness values of $\kappa$-carrageenan-based edible films with glycerol as a plasticizer were $0.03-0.08 \mathrm{~mm}$ (Rusli et al., 2017), which were close to the thickness of the edible film obtained in this study.

\subsection{Water Solubility and Moisture Content}

\subsubsection{Water solubility}

The water solubility of $\kappa$-carrageenan-based edible film at various levels of alginate and PEG varied between $71.03 \pm 0.61 \%$ to $97.23 \pm 0.70 \%$ (Figure 5 ). Water solubility is one of the important properties for the edible film because this parameter indicates the biodegradability of the film (Singh et al., 2015). The

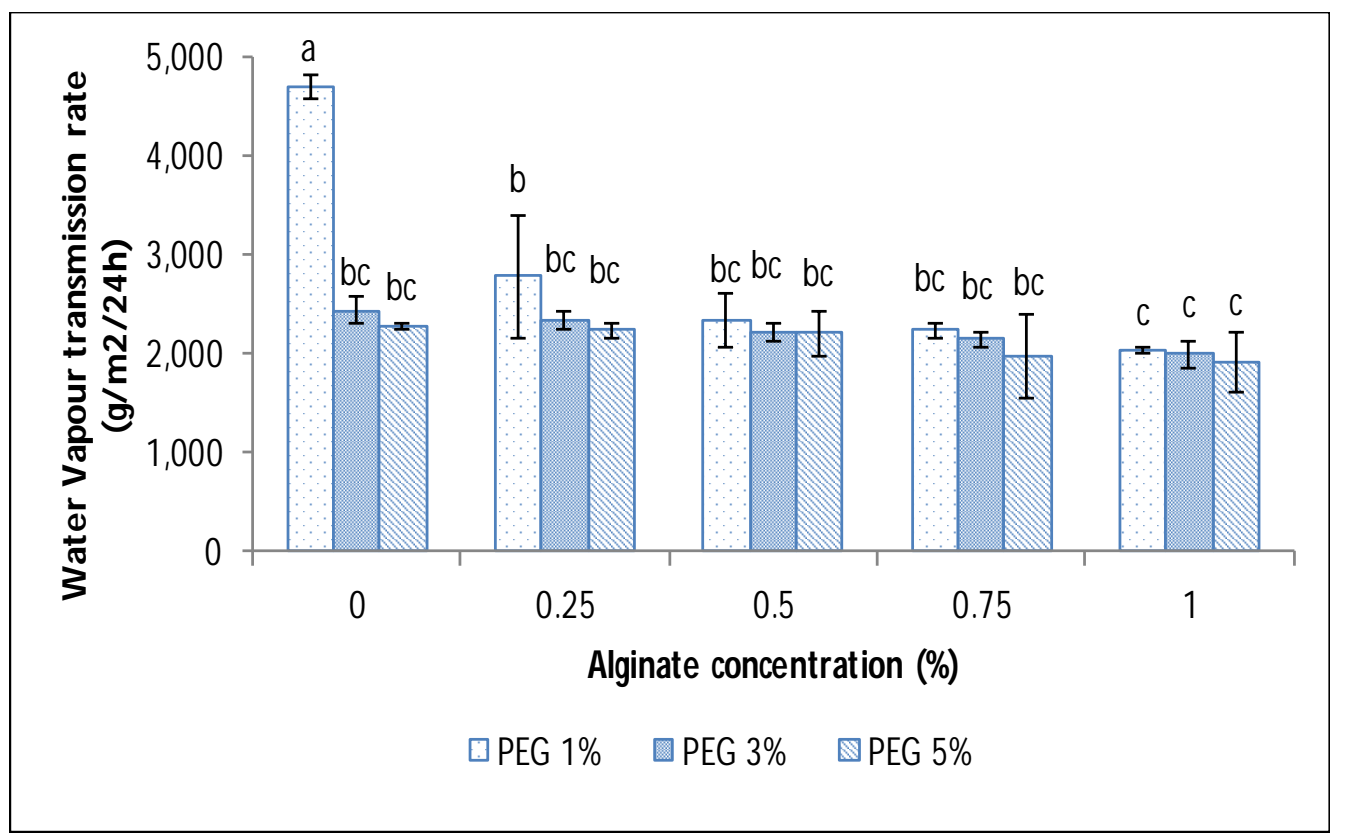

*Note: The same letter in the bar denotes no significant differences $(P>0.05)$

Figure 3. WVTR of $\kappa$-carrageenan-based edible films at different concentrations of alginate and PEG mixture 


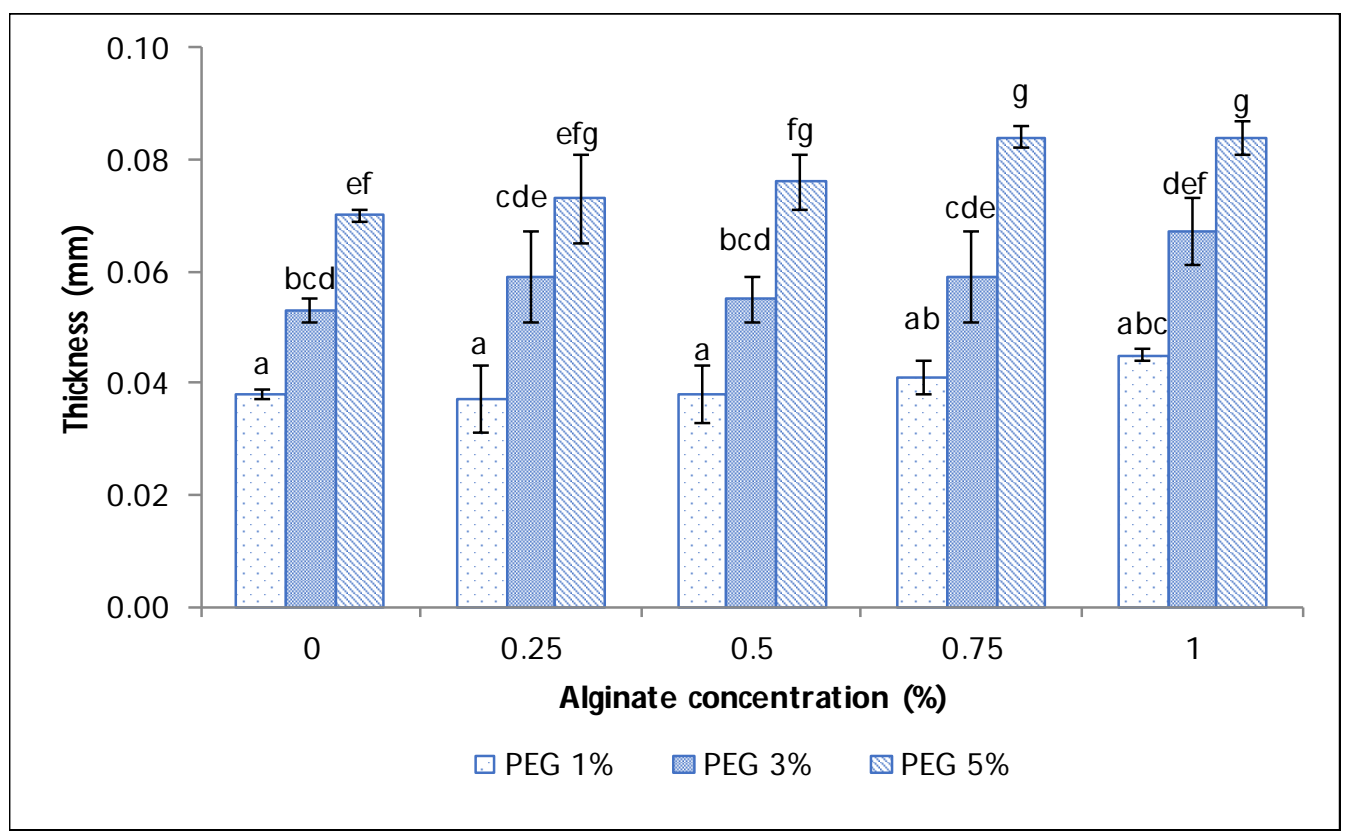

${ }^{*}$ Note: The same letter in the bar denotes no significant differences $(P>0.05)$

Figure 4. Thickness of $\kappa$-carrageenan-based edible films at different concentrations of alginate and PEG

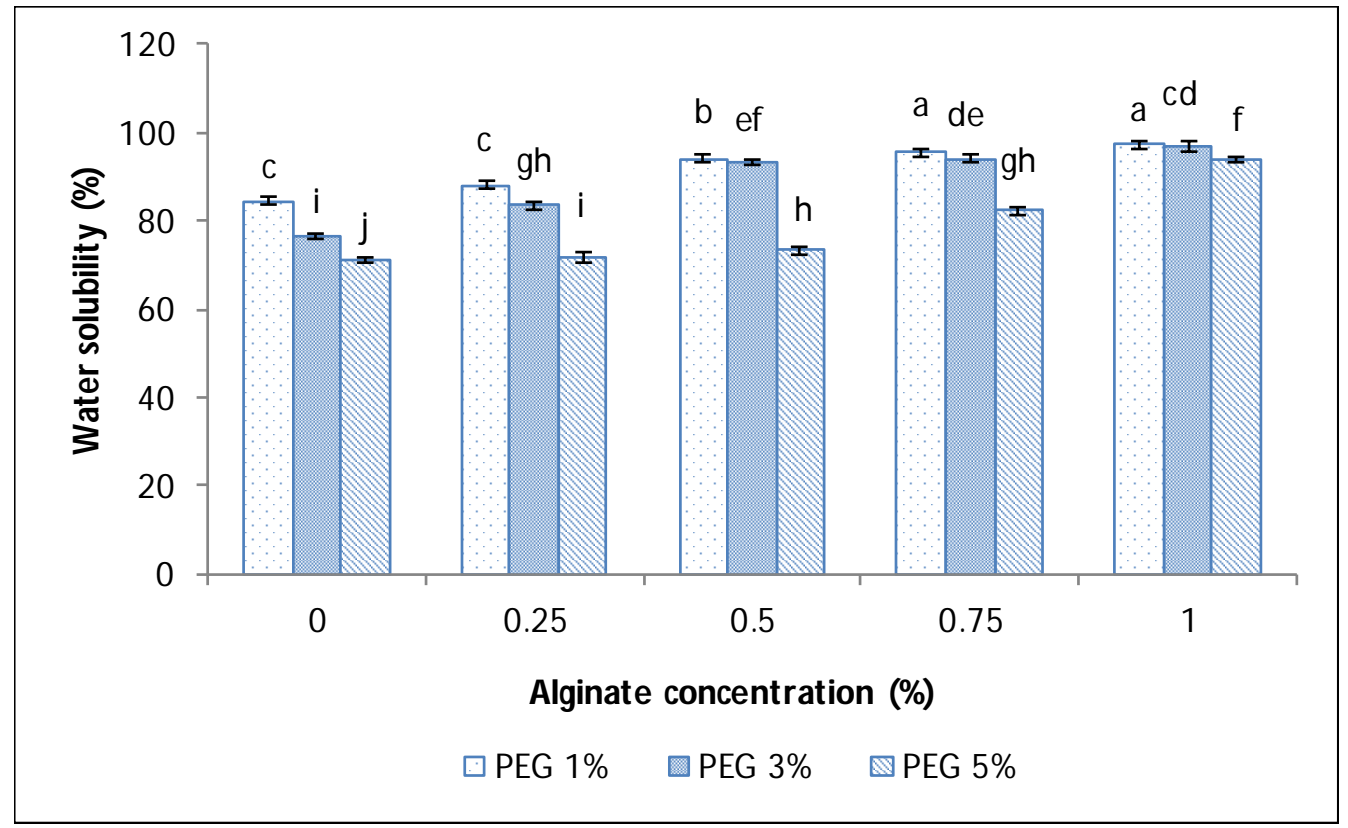

*Note: The same letter in the bar denotes no significant differences $(P>0.05)$

Figure 5. Water solubility of $\kappa$-carrageenan-based edible films at different concentrations of alginate and PEG

$\kappa$-carrageenan-based edible film with the highest water solubility was obtained from the addition of $1 \%$ alginate and $1 \%$ PEG in this study. An edible film with the lowest water solubility was exhibited from film with 0 $\%$ alginate and $5 \%$ PEG. The water solubility of carrageenan-based edible film significantly increased with alginate addition $(P<0.05)$. On the other hand, the water solubility of $\kappa$-carrageenan based edible film significantly decreased with the addition of a higher amount of PEG addition (Figure 5).

The edible films in this study were prepared from carrageenan and sodium alginate with cross-linking through calcium chloride, showed negligible solubility in water (Pascalau et al., 2012). The different methods of film preparation will produce different characteristics of edible films. A possible explanation of that 
occurrence is that the hydroxyl group of PEG increases the water absorption of edible film, but the PEG is not diluted in the water due to the capability of carrageenan and alginate to bind to the water (Balqis et al., 2017; Hambleton, Voilley, \& Debeaufort, 2011). Alginate has the ability to retain and bind water. The water solubility of palm fruit film with PEG as a plasticizer was 54\% (Sitompul \& Zubaidah, 2017), which was lower than the water solubility of $\kappa$ carrageenan-based edible film. Meanwhile, the water solubility of the edible film made from carrageenan and glycerol (as a plasticizer) was $60.51-74.20 \%$ (Rusli et al., 2017), which was slightly lower than that of $\kappa$-carrageenan-based edible film from this study. The edible film with higher water solubility was suggested to be applied in ready to eat products (Pitak \& Rakshit, 2011).

\subsubsection{Moisture content}

The moisture content of the edible films resulted from various levels of alginate and PEG varied from $5.24 \pm 0.83 \%$ to $49.19 \pm 0.47 \%$ in this study (Figure 6 ). The addition of alginate and PEG at different levels affected the moisture content of $\kappa$-carrageenan-based edible films. The addition of alginate reduced moisture content while the addition of PEG increased moisture content. Plasticizers, including PEG increased humectant and water holding capacity of edible film, which bond water being more difficult to evaporate (Rangel-Marrón, Montalvo-Paquini, Palou, \& López-
Malo,, 2013; Sitompul \& Zubaidah, 2017). Therefore, this situation increased the moisture content of the edible film (Ahmadi et al., 2012; Godbillot, Dole, Joly, Rogé \& Mathlouthi , 2006). Low concentrations of polysaccharide (alginate) allowed greater availability of free water to contribute in the polymerization. As a result, it provides a film with higher moisture content (Rangel-Marron et al., 2013). The moisture content of the edible film has an essential role in the stability of coated products. Therefore, the edible film is expected to have low water content; hence it prevents from the addition of water to the product during the application as the primary packaging. As a consequence, it prevents the product from deterioration and increase shelf life (Rusli et al., 2017).

The moisture content of edible films varied depending on the base material, plasticizer, and method used to produce the edible film (Rangel-Marron et al., 2013 Godbillot et al., 2006). Composite films from alginate, gluten, and beeswax have moisture content ranged from $21.95 \%$ to $24.63 \%$; while sugar palm fruit edible film with PEG (as a plasticizer) has moisture content around $21.74 \%$ (Sitompul \& Zubaidah, 2017). Moreover, the moisture content of the $\kappa$-carrageenan-based film with glycerol (as a plasticizer) was about $17.14-20.86 \%$ (Rusli et al., 2017). The moisture contents of the film with $1 \%$ PEG at different concentrations of alginate were lower than the $\kappa$-carrageenan-based edible films prepared using $3 \%$ and $5 \%$ PEG (Figure 6 ).

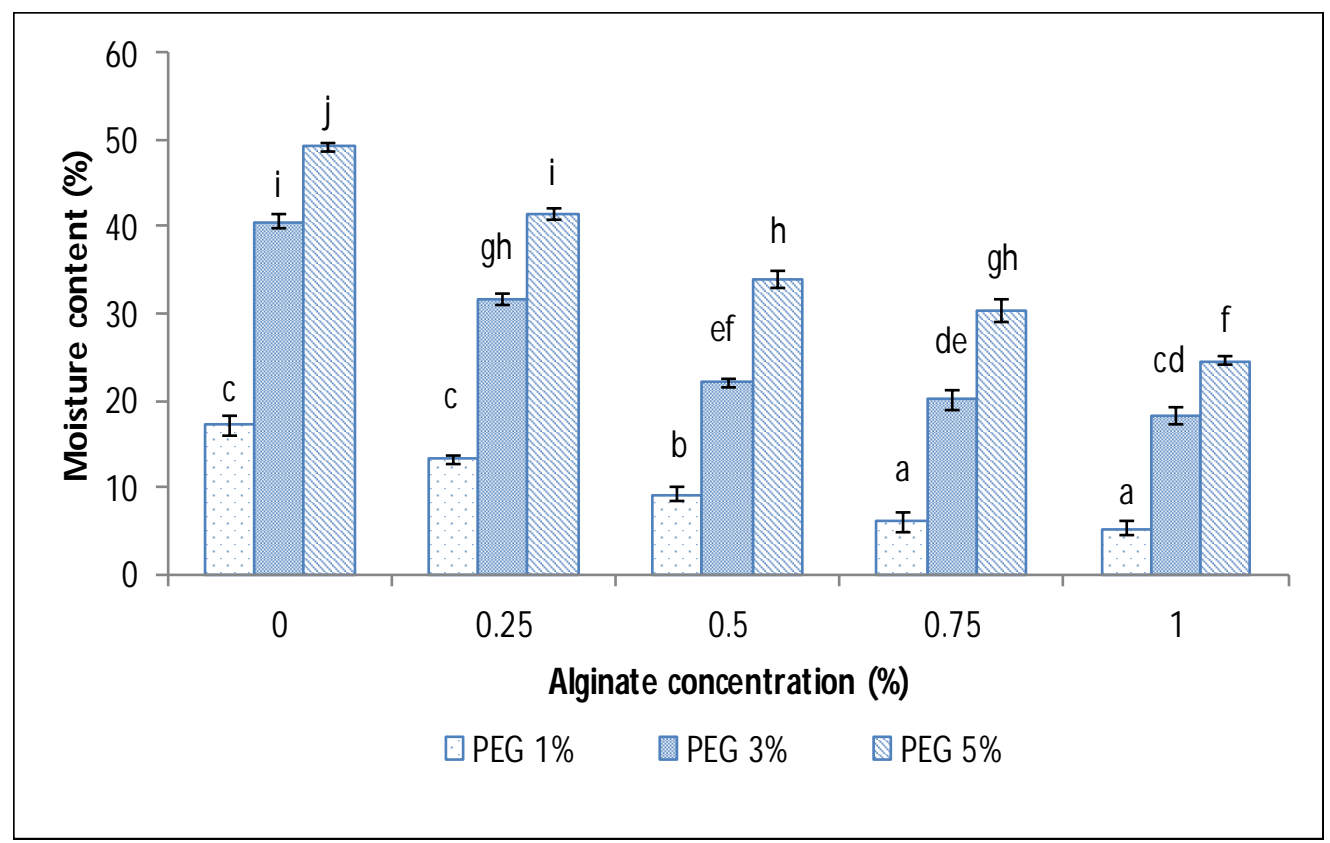

*Note: The same letter in the bar denotes no significant differences $(P>0.05)$

Figure 6. Moisture content of $\kappa$-carrageenan-based edible films added with different concentrations of alginate and PEG 


\section{Conclusion}

Mixing $\kappa$-carrageenan with alginate increased tensile strength, thickness, and water solubility of the edible film, but reduced elongation at break, WVTR, and moisture content. The addition of PEG to $\kappa-$ carrageenan based edible film reduced tensile strength, and water solubility, on the contrary, increased elongation at break, thickness, and moisture content. Overall, $\kappa$-carrageenan based edible film with $1 \%$ alginate and $1 \%$ PEG was considered as the best formula, revealing the lowest WVTR value and moisture content as well as high tensile strength.

\section{Acknowledgments}

This research was funded by the Ministry of Research, Technology and Higher Education of the Republic of Indonesia, through PTUPT program 2019 No: 45.3/USJ-11/H.54/2019. The authors declare that there is no conflict of interest regarding the publication of this article. Main Contributors are Giyatmi, Hari Eko Irianto, Dina Fransiska. While, supporting contributors are Tika Annisa Eka Poetri and Agusman.

\section{References}

Abdel-Rahman, R. M., Abdel-Mohsen, A. M., Fouda, M. M. G., AI Deyab, S. S., \& Mohamed, A. S. (2013). Finishing of cellulosic fabrics with Chitosan/polyethylene glycolsiloxane to improve their Performance and antibacterial properties, Life Science Journal, 10(4), 834-839.

Ahmadi, R., Kalbsi-Ashtari, A., Oromiehie, A., Yarmand, M. S., \& Jahandideh, F. (2012). Development and characterization of a novel biodegradable edible film obtained from psyllium seed (Plantago ovata Forsk). Journal of Food Engineering, 109(4), 745-751. https://doi.org/10.1016/j.jfoodeng.2011.11.010

Bajpai SK, Navin C, Ruchi L. (2011). Water vapour permeation and antimicrobial properties of sago starch based films formed via microwave irradiation. International Food Research Journal, 18(1), 417-426. http://www.ifrj.upm.edu.my/ 18\%20(01)\%202011/(44)\%20IFRJ-2010-148.pdf

Balqis, A. I., Khaizura, M. N., Russly, A. R., \& Hanani, Z. N. (2017). Effects of plasticizers on the physicochemical properties of kappa-carrageenan films extracted from Eucheuma cottonii. International Journal of Biological Macromolecules, 103, 721-732. https://doi.org/ 10.1016/j.ijbiomac.2017.05.105

Bourtoom T. (2008). Plasticizer effect on the properties of biodegradable blend film from rice starchchitosan. Songklanakarin Journal of Science and Technology, 30(1), 150-154.

Cerqueira, M. A., Bourbon, A. I., Pinheiro, A. C., Martins, J. T., Souza, B. W. S., Teixeira, J. A., \& Vicente, A. A. (2011).
Galactomannans use in the development of edible films/coatings for food applications. Trends in Food Science \& Technology, 22(12), 662-671.https:// doi.org/10.1016/j.tifs.2011.07.002

Fardhyanti, D. S. \& Julianur, S. S. (2016). Karakterisasi Edible Film Berbahan dasar ekstrak karagenan dari rumput laut (Eucheuma cottonii). Jurnal Bahan Alam Terbarukan, 4(2), 68-73. https://doi.org/10.15294/ jbat.v4i2.412

Farhan, A. \& Hani, N. M. (2017). Characterization of edible packaging films based on semi-refined kappacarrageenan plasticized with glycerol and sorbitol. Food Hydrocolloids, 64, 48-58. https://doi.org/ 10.1016/j.foodhyd.2016.10.034

Fransiska, D., Giyatmi, G., Irianto, H. E., Darmawan, M., \& Melanie, S. (2018). Karakteristik Film k-karaginan dengan Penambahan Plasticizer Polietilen GlikolCharacteristics of k-Carrageenan Film with Polyethylene Glycol as Plasticizer. Jurnal Pascapanen dan Bioteknologi Kelautan dan Perikanan, 13(1), 1320.

García, M. A., Pinotti, A., Martino, M. N., \& Zaritzky, N. E. (2009). Characterization of starch and composite edible films and coatings. In Edible films and coatings for food applications. In K. C. Huber \& M. E. Embuscado (Eds.) (pp. 169-209), Springer, New York, NY. https://doi.org/10.1007/978-0-387-92824-1_6

Godbillot, L., Dole, P., Joly, C., Rogé, B., Mathlouthi, M. (2006). Analysis of water binding in starch plasticized films. Food Chemistry, 96(3), 380-386. https://doi.org/ 10.1016/j.foodchem.2005.02.054

Hambleton, A., Voilley, A., \& Debeaufort, F. (2011). Transport parameters for aroma compounds through $\mathrm{i}$-carrageenan and sodium alginate-based edible films. Food Hydrocolloids, 25(5), 1128-1133.

Han, J. \& Gennadios, A. (2005). Edible Films and Coatings: A Review. In J. Han (Ed.), Innovations in Food Packaging (pp. 239-262), Elsevier

Imeson, A. P. (2000). Carrageenan. In G. O. P. and P. A. Williams (Ed.), Handbook of hydrocolloids. Cambridge: Woodhead Publishing Limited.

KKP. (2014). Laporan Tahunan Direktorat Produksi Tahun 2013. Direktorat Jenderal Perikanan Budidaya. Jakarta (ID) : Kementerian Kelautan dan Perikanan.

Krochta, J. M. \& De Mulder-Johnston, C. (1997). Edible \& biodegradable polymer films: Challenges and opportunities. Food Technology (Vol. 51).

Larotonda, F. D. S., Torres, M. D., Gonçalves, M. P., Sereno, A. M., \& Hilliou, L. (2016). Hybrid carrageenan-based formulations for edible film preparation: Benchmarking with kappa carrageenan. Journal of Applied Polymer Science, 133(2), 1-10. https://doi.org/10.1002/app.42263

Lee, K. Y. \& Mooney, D. J. (2012). Alginate: properties and biomedical applications. Progress in Polymer Science, 37(1), 106-126. https://doi.org/10.1016/ j.progpolymsci.2011.06.003.

Lismawati. (2017). Pengaruh panambahan plasticizer gliserol terhadap karakteristik edible film dari pati kentang (Solanum tuberosum) [Bachelor Thesis]. 
Universitas Islam Negeri Alauddin Makassar. Makassar

Marpongahtun, C. F. Z. (2016). Physical-Mechanical properties and microstructure of Breadfruit starch edible films with various plasticizer. Jurnal Eksakta UII, 13(1-2), 56-62. https://doi.org/10.20885/ eksakta.vol13.iss1-2.art7

Ma, D., Jiang, Y., Ahmed, S., Qin, W., \& Liu, Y. (2019). Physical and antimicrobial properties of edible films containing Lactococcus lactis. International Journal of Biological Macromolecules, 141, 378-386. https:/ /doi.org/10.1016/j.ijbiomac.2019.09.006

Meng, F., Zhang, Y., Xiong, Z., Wang, G., Li, F., \& Zhang, L. (2018). Mechanical, hydrophobic and thermal properties of an organic-inorganic hybrid carrageenan-polyvinyl alcohol composite film. Composites Part B: Engineering, 143, 1-8. https:// doi.org/10.1016/j.compositesb.2017.12.009

Menon, V. V. (2011). Seaweed Polysaccharides-Food Applications. In Handbook of Marine Macroalgae (pp. 541-555), John Wiley \& Sons, Ltd. https://doi.org/ 10.1002/9781119977087.ch36

Murdinah, Darmawan, M., \& Fransiska, D. (2007). Karakteristik Edible Film dari Komposit Alginat, Gluten dan Lilin Lebah (Beeswax). Jurnal Pascapanen Dan Bioteknologi Kelautan Dan Perikanan, 2(1), 19-25. https://doi.org/10.15578/jpbkp.v2i1.30

Murni, S. W., Pawignyo, H., Widyawati, D., \& Sari, N., (2013). Pembuatan Edible Film dari Tepung Jagung (Zea Mays L.) dan Kitosan. Prosiding Seminar Nasional Teknik Kimia Kejuangan (p. B17 1-9).

Olivas, G. I., \& Barbosa-Cánovas, G. V. (2008). Alginatecalcium films: Water vapor permeability and mechanical properties as affected by plasticizer and relative humidity. $L W T$ - Food Science and Technology, 41(2), 359-366. https://doi.org/10.1016/ j.Iwt.2007.02.015

Page, M.C., Braver, S.L., \& Mackinnon, D.P. (2003) Levine's guide to SPSS for analysis of variance 2nd ed. Lawrence Erlbaum Associates, Inc., Publishers. New Jersey

Pascalau, V., Popescu, V., Popescu, G. L., Dudescu, M. C., Borodi, G., Dinescu, A., ... Paul, M. (2012). The alginate/k-carrageenan ratio's influence on the properties of the cross-linked composite films. Journal of Alloys and Compounds, 536(SUPPL.1), 418-423.

j.jallcom.2011.12.026

Pavlath, A. E., \& Orts, W. (2009). Edible Films and Coatings: Why, What, and How? BT - Edible Films and Coatings for Food Applications. In K. C. Huber \& M. E. Embusc. Springer, New York, NY, USA.

Peranginangin, R., Rahman, A., \& Irianto, H. E. (2011) Pengaruh Perbandingan Air Pengekstrak dan Penambahan Celite Terhadap Mutu KappaCarrageenan (Effects of Extraction Water Proportion and Celite Addition on Kappa-Carrageenan Quality). Inovasi Teknologi Akulturasi, 1077-1086.

Pitak, N., \& Rakshit, S. K., (2011). Physical and antimicrobial properties of banana flour/chitosan biodegradable and self sealing films used for preserving fresh-cut vegetables. $L W T$ - Food Science and Technology, 44(10), 2310-2315. https://doi.org/ 10.1016/j.Iwt.2011.05.024

Prachayawarakorn, J., \& Pomdage, W. (2014). Effect of carrageenan on properties of biodegradable thermoplastic cassava starch/low-density polyethylene composites reinforced by cotton fibers. Materials \& Design, 61, 264-269. https://doi.org/ 10.1016/J.MATDES.2014.04.051

Rachmawati, N., Triwibowo, R., \& Widianto, R. (2015). Mechanical Properties and Biodegradability of AcidSoluble Chitosan-Starch Based Film. Squalen Bulletin of Marine \& Fisheries Postharvest \& Biotechnology, 10(1), 1-7.

Rajendran, N., Puppala, S., Raj, Sneha, M., B, R. A., \& Rajam, C. (2012). Seaweeds can be a new source for bioplastics Seaweeds can be a new source for bioplastics. Journal of Pharmacy Research 2012,5(3), 1476-1479, 5(3), 1476-1479.

Rangel-Marrón, M., Montalvo-Paquini, C., Palou, E., \& López-Malo, A. (2013). Optimization of the moisture content, thickness, water solubility and water vapor permeability of sodium alginate edible films. Recent Advances in Chemical Engineering, Biochemistry and Computational Chemistry Optimization, 72-78.

Razzaq, H. A. A., Pezzuto, M., Santagata, G., Silvestre, C., Cimmino, S., Larsen, N., \& Duraccio, D. (2016). Barley $\alpha$-glucan-protein based bioplastic film with enhanced physicochemical properties for packaging. Food Hydrocolloids, 58, 276-283. https://doi.org/10.1016/ j.foodhyd.2016.03.003

Rodriguez, A., Madera, T., \& Pelegrín, Y. F. (2018). Formulation, properties and performance of edible films and coatings from marine sources in vegetables and fruits. In M. A. Masuelli (Ed.), Bioapackaging (pp. 90-191). New York: CRC Press Boca Raton.

Rusli, A., Metusalach, S., Tahir, M. M., 2017. Karakterisasi edible film karaginan dengan pemlastis gliserol. Jurnal Pengolahan Hasil Perikanan Indonesia, 20(2), 219-229.

Salmieri, S. \& Lacroix, M. (2006). Physicochemical properties of alginate/polycaprolactone-based films containing essential oils. Agricultural and Food Chemistry, 54, 10205- 10214

Sánchez-Ortega, I., García-Almendárez, B. E., SantosLópez, E. M., Amaro-Reyes, A., Barboza-Corona, J. E., \& Regalado, C. (2014). Antimicrobial edible films and coatings for meat and meat products preservation. The Scientific World Journal, 2014, 248935. https://doi.org/10.1155/2014/248935.

Šešlija, S., Nešiæ, A., Ružiæ, J., Kalagasidis Krušiæ, M., Velièkoviæ, S., Avolio, R., ... Malinconico, M. (2018). Edible blend films of pectin and poly(ethylene glycol): Preparation and physico-chemical evaluation. Food Hydrocolloids, 77, 494-501. https://doi.org/10.1016/ j.foodhyd.2017.10.027

Singh, T. P., Chatli, M. K., \& Sahoo, J. (2015). Development of chitosan based edible films: process optimization 
using response surface methodology. Journal of Food Science and Technology, 52(5), 2530-2543. https://doi.org/10.1007/s13197-014-1318-6

Sitompul, A. J. W. S., \& Zubaidah, E. (2017). Pengaruh Jenis dan Konsentrasi Plasticizer terhadap Sifat Fisik Edible Film Kolang Kaling ( Arenga pinnata ). Pangan dan Agroindustri, 5(1), 13-25.

Skurtys, O., Acevedo, C., Pedreschi, F., Enronoe, J., Osorio, F., \& Aguiler, J. M. (2010). Food hydrocolloid edible films and coatings. Nova Science Publishers, Inc (US).

SNI. (2014). SNI 7818:2014 Kantong Plastik Mudah Terurai. Jakarta (ID) : Badan Standarisasi Nasional.

Sothornvit, R., \& Rodsamran, P. (2008). Effect of a mango ûlm on quality of whole and minimally processed mangoes. Postharvest Biology and Technology, 47(3), 407-15 j.postharvbio.2007.08.005

Suryaningrum, T. D., Basmal, J., \& Nurochmawati, N. (2005). Studi pembuatan edible film dari karaginan.
Journal Penelitian Perikanan Indonesia, 11(4). https:/ /doi.org/ttp://dx.doi.org/10.15578/jppi.11.4.2005.1-13.

Tavassoli-Kafrani, E., Shekarchizadeh, H., \& MasoudpourBehabadi, M. (2016). Development of edible films and coatings from alginates and carrageenans. Carbohydrate Polymers, 137, 360-374. https:// doi.org/10.1016/j.carbpol.2015.10.074

Wypych, G. (2004). Handbook of plasticizers. Ontario: ChemTec.

Ye, Z., Ma, P., Tang, M., Li, X., Zhang, W., Hong, X., ... \& Chen, D. (2017). Interactions between calcium alginate and carrageenan enhanced mechanical property of a natural composite film for general packaging application. Polymer Bulletin, 74(8), 3421-3429. https://doi.org/10.1007/s00289-016$1894-x$

Yunizal (2000). Penelitian Teknologi Ekstraksi Alginat dari Rumput Laut Coklat (Phaeophyceae). Balai Penelitian Perikanan Laut, Jakarta. 100 pp. 